\title{
MENINGKATKAN PENDAPATAN PETANI MELALUI DIFERSIVIKASI TANAMAN HORTIKULTURA DI LAHAN SAWAH IRIGASI
}

\author{
Tjetjep Nurasa
}

\author{
Peneliti di Pusat Analisis Sosial Ekonomi Pertanian. Bogor
}

\begin{abstract}
Farmers in the paddy field farming faces some fundamental problems caused by the narrower tenure due to increased population and land inheritance, creation of breakthrough technologies to increase the productivity of rice farming and farmers' income increasingly difficult for farmers to diversify motives are often more oriented to the income stabilization. West Java is better known as the rice granary, is also a center of vegetables in Indonesia. Vegetable farming has been fused with the local community, especially for upland farmers. The last few years this development not only in vegetable crops in the highlands but try also try in the lowlands in the paddy field. Along with the above conditions, the policy support necessary to achieve the expected results. One obstacle in the application of vegetable farming is the lack of use of the means of production as a result of lack of financial ownership of farm households. The purpose of research is (a) reveals variability of farm crops especially vegetables Onion, Long Beans, cauliflower and cucumbers. (b). And to evaluate the extent to which government policy support for horticultural commodities especially vegetables in West Java. The research was conducted in two districts of Indramayu (Chilli Red, Red Onion and Cauliflower), Falkirk (cucumber and bean length) of West Java Province. , Amounted to a total of 50 respondents drawn farmers. The results showed that farm incomes various vegetables (horticulture) is higher than the income of rice farming, especially in the red pepper $(673 \%)$, onions $(415 \%)$, while the rate of return based on a variety of vegetable farming is higher than the benefits of rice farming, especially red pepper (776\%), onions (279\%) cauliflower (200\%) and beans $(144 \%)$
\end{abstract}

Keywords : variability farm crops, horticulture, farm income

\section{PENDAHULUAN}

Pendapatan yang rendah dan kemiskinan merupakan masalah utama dalam pembangunan ekonomi di negara berkembang. Dengan demikian dalam tujuan pembangunan ekonomi kedua hal tersebut selalu dinyatakan bersamaan sehingga menjadi satu kalimat yaitu peningkatan pendapatan nasional dan pengurangan kemiskinan (Suhardjo, 1997). Ketimpangan pendapatan di pedesaan banyak dipengaruhi oleh kondisi agroekosistem setempat (Sarasutha dan Noor, 1994). Wilayah berproduktivitas rendah mempunyai hubungan timbal balik dengan kemiskinan, baik sebagai penyebab maupun sebagai akibat. Oleh karena itu, suatu wilayah yang tingkat produktivitasnya rendah dapat mengakibatkan masyarakatnya miskin. Demikian pula sebaliknya, ketidakmampuan masyarakat mengelola sumberdaya mengakibatkan wilayah itu miskin. Struktur pendapatan rumah tangga di pedesaan bervariasi tergantung pada keragaman sumberdaya pertanian. Menurut Rachman dan Hadimuslihat (1989) dan Adnyana et. al. (2000) keragaman sumberdaya mempengaruhi struktur pendapatan rumah tangga pedesaan. Sumber pendapatan rumah tangga di suatu lokasi erat kaitannya dengan agroekosistem lokasi tersebut. Secara umum agroekosistem pedesaan dapat dibagi ke dalam dua klasifikasi yaitu lahan basah (sawah) dan lahan kering.

Hasil penelitian cukup banyak yang menyebutkan bahwa diversifikasi kondusif untuk meningkatkan pendapatan. Pada agroekosistem sawah, komoditas non padi yang populer adalah palawija dan atau hortikultura 


\section{Tjetjep Nurasa : Meningkatkan Pendapatan Petani Melalui Difersivikasi Tanaman ...}

dataran rendah (melon, bawang merah, cabai, dan sebagainya). Pada umumnya diusahakan pada Musim Tanam (MT) II dan atau MT III. Pendapatan usahatani diversifikasi lebih stabil dan untuk yang mengusahakan komoditas hortikultur peningkatannya cukup besar (Saliem dan Supriyati, 2006). Meskipun pengusahaan komoditas per-tanian bernilai ekonomi tinggi dapat mening-katkan pendapatan yang cukup besar namun tingkat partisipasi petani untuk menerapkannya masih relatif rendah. Dalam hal ini hasil penelitian (Sumaryanto, 2006) menunjukkan bahwa faktor-faktor yang berpengaruh positif terhadap probabilitas petani untuk berdiversi-fikasi adalah jumlah anggota rumah tangga yang bekerja di usahatani, kemampuan per-modalan, peranan usahatani dalam ekonomi rumah tangga, tingkat kelangkaan air irigasi, dan kepemilikan pompa irigasi. Faktor yang tidak kondusif adalah fragmentasi lahan garapan.

Usahatani termasuk aktivitas ekonomi dengan risiko dan ketidak pastian tinggi (fluktuasi pendapatan antar siklus produksi atau-pun antar tahun cukup tinggi). Oleh karena itu motif petani untuk berdiversifikasi seringkali lebih beriorientasi pada stabilisasi pendapatan daripada maksimisasi pendapatan. Strategi untuk meminimalkan risiko dapat dipilah menjadi 5 macam yaitu: (i) strategi produksi, (ii) strategi pemasaran, (iii) strategi finansial, (iv) pemanfaatan kredit informal, dan (v) menjadi peserta asuransi pertanian. Di Indonesia strategi yang banyak diterapkan adalah strategi produksi (Hadi et al., 2000; Susilowati et al., 2002). Penerapan teknik budidaya untuk diversifikasi usahatani sebagai upaya mengurangi risiko produksi (Petit and Barghouti, 1992; Schnep et al., 2001).

Diversifikasi usahatani merupakan salah satu program pokok pembangunan pertanian di samping program ekstensifikasi, intensifikasi dan rehabilitasi. Program pengembangan diversifikasi usahatani di lahan sawah dikaitkan dengan upaya peningkatan pendapatan, perluasan kesempatan kerja dan penanggulangan kemiskinan, merupakan salah satu pilihan strategi yang tepat. Sejak Pelita I (19741978), pemerintah telah mengembangkan program diversifikasi usahatani, namun dalam perkembangannya, program tersebut belum menunjukkan kinerja seperti yang
diharapkan.Hasil studi empirik menunjukkan bahwa pendapatan rumah tangga pada daerah non-rice base farming cenderung lebih tinggi dibandingkan dengan daerah berbasis padi dan perkembangan ekonomi pada wilayah ini mengalami kejenuhan. Petani di lahan sawah menghadapi beberapa permasalahan pokok usahatani antara lain: (a) Penguasaan lahan semakin sempit karena peningkatan jumlah penduduk dan pewarisan lahan, (b) Penciptaan terobosan teknologi usahatani padi untuk meningkatkan produktivitas dan pendapatan petani semakin sulit, dan (c) Petani menghadapi kendala teknis, sosial, dan ekonomi untuk mengembangkan komoditas nonpadi yang lebih menguntungkan (Supriyati et.al., 2005).

Siegler (1977) dalam Pakpahan (1989) menyebutkan bahwa diversifikasi berarti perluasan dari suatu produk yang diusahakan selama ini ke produk baru yang sebelumnya tidak diusahakan. Adapun beberapa tujuan dalam melakukan diversifikasi menurut Siegler (1977) dalam Pakpahan (1989) antara lain adalah (1) meminimumkan risiko, (2) menghindari akibat buruk dari fluktuasi ekonomi, dan (3) sebagai sumber pertumbuhan baru. Perkembangan diversifikasi usahatani dan pilihan pola tanam bersifat dinamis, sangat dipengaruhi faktor-faktor teknis, sosial ekonomi dan kebijakan. Kinerja dan perilaku petani dalam melakukan diversifikasi usahatani dan pilihan pola tanam adalah kompleks. Menurut Pakpahan (1989), hubungan antara diversifikasi dengan keuntungan atau pendapatan petani bersifat kondisional.

Alasan petani mengusahakan komoditas nonpadi antara lain (1) komoditas cabai memberikan besaran (magnitude) dan kontinuitas pendapatan yang relatif tinggi dibanding padi, dan (2) kacang panjang dan paria memberikan pendapatan yang relatif kontinyu (Supriyati dan Rachman, 2003). Tingkat pendapatan usahatani petani yang melakukan diversifikasi lebih tinggi dari petani nondiversifikasi; dalam hal ini pengusahaan komoditas hortikultura memberikan tingkat pendapatan yang relatif lebih tinggi daripada palawija, namun pengusahaan hortikultura membutuhkan modal dan risiko usaha yang juga tinggi.( Handewi P. Saliem dan Supriyati 200) 


\section{Tjetjep Nurasa : Meningkatkan Pendapatan Petani Melalui Difersivikasi Tanaman ...}

\section{METODE PENELITIAN}

Tulisan ini merupakan bagian dari hasil penelitian Patanas (Panel Petani Nasional ) periode tahun 2010. Penelitian ini dilaksanakan di 2 kabupaten yaitu Kabupaten Indramayu (Cabai Merah, Bawang Merah dan Bunga Kol), Karawang (Timun dan Kc Panjang) Propinsi Jawa Barat. Pengumpulan data dilakukan dengan dua cara, yaitu pengumpulan data yang dilakukan wawancara langsung dengan 10 responden per rumahtangga petani penggarap per komoditas sayuran dalam bentuk kuesioner, total responden yang diambil berjumlah 50 petani, terstruktur dari penelitian PATANAS 2010 dimana pada tahun 2010, penelitian PATANAS ditujukan untuk komoditas berbasis padi. Sementara data sekunder diperoleh dari hasil kompilasi di perpustakaan atau informasi terkait. Analisis data, menggunakan analisis statistik deskriptif dengan tabulasi silang dan time series.

Profitabilitas usahatani dalam kajian ini didefinisikan sebagai selisih antara penerimaan usahatani dan biaya tunai usahatani atau biaya yang betul-betul dikeluarkan oleh petani.

Biaya usahatani yang diperhitungkan meliputi: biaya pupuk, biaya tenaga kerja, biaya benih, biaya pestisida, biaya pengairan, pajak lahan, biaya penanganan pasca panen/pengolahan, biaya pengangkutan dan biaya lain yang terkait.

Analisis dilakukan dengan menggunakan analisis anggaran parsial. Indikator analisis yang dipakai adalah $\mathrm{R} / \mathrm{C}$ ratio (Return Cost Ratio). Soekartawi (2002) menyebutkan bahwa $\mathrm{R} / \mathrm{C}$ ratio adalah perbandingan (nisbah) antara penerimaan dan biaya. Secara matematik, hal ini dapat dituliskan sebagai berikut :

$$
\begin{aligned}
\text { RC Ratio } & =\text { Py. Y } \\
\text { R } & =\text { Py.Y } \\
\mathrm{T} \mathrm{C} & =\mathrm{FC}+\mathrm{VC} \\
\mathrm{A} & =(\mathrm{Py} . \mathrm{Y}) /(\mathrm{FC}+\mathrm{VC})
\end{aligned}
$$

Dimana $\mathbf{R}$ adalah Penerimaan, $\mathbf{Y}$ adalah jumlah Produksi/tangkapan, TC adalah Biaya Total, FC adalah biaya tetap fixed cost), Py adalah Harga, VC adalah Biaya tetap (variabel cost)
Jika : a $>1$ maka dikatakan layak,

a $<1$ maka dikatakan tidak layak dan

$\mathrm{a}=1$ maka dikatakan impas (tidak untung maupun merugi)

\section{HASIL DAN PEMBAHASAN}

\section{Persepsi Petani Terhadap Usahatani Komoditas Hortikultura}

Komoditas non padi yang ditanam petani di pedesaan contoh diversifikasi komoditas hortikultura bagi usahatani padi yaitu ; cabe merah, kembang kol, kacang panjang, ketimun dan bawang merah. Kriteria penetapan komoditas tersebut sebagai komoditas diversifikasi padi adalah komoditas yang dominan ditanam pada musim yang sama dan menjadi alternative komoditas padi karena pertimbangan ekonomi.

Kabupaten Kerawang, Subang maupun Indramayu pola tanam dominan di sawah irigasi teknis adalah padi-padi-bera. Namun dalam beberapa tahun terakhir ini di beberapa kecamatan di kabupaten-kabupaten Krawang, Subang dan Indramayu telah terjadi perubahan pola tanam di sawah irigasi teknis dari padipadi-bera menjadi padi-sayuran-bera atau sayuran-sayuran-bera. Sayuran yang dibudidayakan adalah sayuran dataran rendah seperti kacang panjang, cabai, dan bunga kol. Jadi tanaman-tanaman ini boleh dikategorikan sebagai tanaman diversifikasi padi. Luas tanam tanaman-tanaman diversifikasi padi tersebut dari tahun ke tahun cenderung meningkat meskipun peningkatannya tidak signifikan. Hal ini disebabkan: (1) Tanaman khususnya sayuran bukan makanan pokok; (2) pasar komoditas sayuran masih terbatas; (3) benih sayuran yang berkualitas masih terbatas; (4) kebutuhan tenaga kerja yang relatif tinggi untuk perawatan/pemeliharaan tanaman sayuran; dan (6) peningkatan produksi padi/beras masih menjadi prioritas pemerintah.

Tanaman komoditas hortikultura perkembangannya semakin tahun nampaknya cenderung meningkat. Dari beberapa komoditas hortikultura (sayuran) menurut pendapat responden bahwa yang dominan diusahakan di musim hujan adalah bawang merah dan cabe merah, masing-masing sekitar $60 \%$ dan 33\%,

Ada beberapa alasan petani menanam komoditas sayuran (komoditas kacang panjang 


\section{Tjetjep Nurasa : Meningkatkan Pendapatan Petani Melalui Difersivikasi Tanaman ...}

dan ketimun) dilahan sawah, 1) Tanaman hortikultura (sayuran) lebih menguntungkan dari segi pendapatan dibandingkan padi. 2) Dari faktor irigasi dan adanya program pemerintah, bahwa menyatakan bahwa pengairan untuk padi tidak mencukupi, 3) karena kebiasaan atau turun temurun pada petani yang menanam komoditas ketimun.

Beberapa alasan indikator petani menanam komoditas Hortikultura (sayuran); 1) jika harga rendah dan kebiasaan petani, adalah pada komoditas ketimun, kembang kol, dan kacang panjang,. 2) berdasarkan kebiasaan petani tetap menanam ada pada komoditas ketimun. 3) biaya komoditasi lebih rendah, penanganan budidaya lebih mudah serta serta umur tanaman lebih pendek pada petani kacang panjang. 4) adanya permintaan yang cukup tinggi pada petani cabai, 5) keuntungan yang lebih tinggi pad petani (ketimun, kembang kol dan kacang panjang). Didalam petani mengambil keputusan tetap menanam komoditas hortikultura (sayuran jika serangan hama dapat diatasi dengan mudah, walaupun biaya yang dikeluarkan relatif cukup besar, adalah seluruh petani komoditas hortikultura (sayuran), sedangkan bahwa adanya permintaan tinggi dan keuntungan lebih baik dari padi, adalah petani ketimun dan petani kembang kol.

Komoditas hortikultura umumnya masih banyak komoditas yang belum tersentuh adanya program pemerintah maupun swasta, terutama dari input produksinya dan pemasarannya. Tetapi kenyataan dilapang bagi petani yang menyatakan 100 persen menyatakan tetap menanam tanaman sayuran karena kesesuaian komoditas yang ditanam sesuai dengan agosistem. permintaan tinggi dan keuntungan lebih tinggi adalah petani dikabupaten karawang (Kc.panjang), Indramayu (kembang Kol) dan sisanya pendapat petani menyatakan kurang dari 80 persen bahwa budidaya lebih muda, umur tanaman lebih pendek dan kebiasaan petani tetap menanam walaupun bantuan pemerintah sangat rendah atau tidak ada sama sekali. (Tabel 1). Pengetahuan petani hortikultura umumnya lebih luas dibanding petani padi, karena tanaman hortikultura sangat kompleks permasalahan yang dihadapi, baik dari penggunaan benih unggul, pengolahan tanah, pengairan, pemupukan, dan hama penyakit dalam pemakaian obat-obatan. Bila tidak ditangani dengan lebih seirus, kerugian yang dihadapi dapat 3 kali lipat dari pendapatan yang diterima. Resiko ekstra hati-hati yang dihadapi bagi petani adalah terutama petani petani cabai merah, bawang merah, kembang kol dibandingkan tanaman hotikultura lainnya. Ada beberapa keputusan petani menanam komoditas sayuran di lahan sawah yakni bahwa komoditas sayuran sangat cocok ditanam di lahan sawah. Beberapa pandangan/persepsi petani komoditas hortikultura (sayuran), yang tidak kalah pentingnya adalah modal yang ditanggung dalam budidaya yang dihadapi seperti, modal kerja, benih, tenaga kerja, obat-obatan dan pemasaran.

Tabel 1. Alasan petani bila tidak ada program pemerintah untuk komoditas sayuran tetap menanam (\%)

\begin{tabular}{cccccccc}
\hline Jagung & $\begin{array}{c}\text { Kede } \\
\text { le }\end{array}$ & $\begin{array}{c}\text { Kacang } \\
\text { tanah }\end{array}$ & $\begin{array}{c}\text { Bawang. } \\
\text { Merah }\end{array}$ & Mentimun & $\begin{array}{c}\text { Cabe } \\
\text { merah }\end{array}$ & $\begin{array}{c}\text { Kembamg } \\
\text { Kol }\end{array}$ & Kacang. panjang \\
\hline 66.67 & 93.55 & - & 40.00 & - & 13.33 & 20.00 & 10.00 \\
55.56 & 6.45 & 10.00 & 20.00 & 50.00 & 40.00 & 100.00 & 100.00 \\
11.11 & 32.26 & 100.00 & 80.00 & 83.33 & 60.00 & 60.00 & 100.00 \\
44.44 & 12.90 & 60.00 & - & 16.67 & 20.00 & 40.00 & 20.00 \\
22.22 & 3.23 & 10.00 & 20.00 & 66.67 & 13.33 & - & 70.00 \\
44.44 & - & 70.00 & - & 83.33 & 33.33 & - & 10.00 \\
\hline
\end{tabular}




\section{Tjetjep Nurasa : Meningkatkan Pendapatan Petani Melalui Difersivikasi Tanaman ...}

Tabel 2 Dari beberapa indikator tersebut terutama kesulitan dalam memperoleh modal $(100 \%)$ hanya petani bawang merah sedangkan petani komoditas sayuran lainnya kesulitannya sekitar $40 \%$ sampai $80 \%$. Untuk memperoleh benih, petani bawang merah menyatakan 80 persen sulit memperoleh benih, hal ini dikarenakan benih yang digunakan bukan benih unggul melainkan benih hasil produksi sendiri, sehingga hasil pendapatan yang diterima relatif rendah yang dikarenakan kualitas yang kurang baik.

Aspek ketenagakerjaan rata-rata tidak mengalami kesulitan,(hanya sekitar 10\% sampai 30\%), hal ini dikarenakan kebutuhan tenaga kerja disetiap lokasi tercukupi, artinya petani tidak perlu mencari tenaga kerja sampai ke luar desa, seperti tenaga kerja pemeliharaan dan panen.

Begitu pula halnya dengan obat-obatan, petani tidak sulit untuk mendapatkannya, umumnya di setiap lokasi pengadaan obat seperti kios saprodi sudah banyak tersedia, didesa, bahkan sampai kedusun disetiap desa, walaupun harga berbeda antar desa dan dusun.
Tetapi saat petani membutuhkan kebanyakan tidak melihat berapa besarnya harganya, dan kedua untuk memperolehnya dapat dibayar setelah panen.

Aspek penyimpanan hasil, terlihat hanya petani cabai merah dibandingkan petani komoditas lainnya yang menyatakan cukup sulit untuk menyimpan hasil panen, hal ini komoditas tersebut sangat rentan akan suhu penyimpanan yang kurang baik. Sehingga jika tempat penyimpanan hasil yang kurang baik, cabai merah akan cepat busuk, dan kalaupun dijual harga akan jatuh. Dari segi pemasaran nampaknya seluruh petani komoditas sayuran tidak mengalami kesulitan dalam menjual hasil panen, karena banyak pedagang atau bakul yang merupakan kaki tangan pedagang diatasnya yang beroperasi didesa pada satt panen, kalaupun ada hanya $6 \%$ kesulitannya, itupun petani harus menjualnya hanya sampai luar desa tetapi masih dalam satu kecamatan. Lebih rinci uraian persepsi petani menghadapi berbagai kesulitan dalam usahatani tertera dalam Tabel 2.

Tabel 2. Kendala Petani Menghadapi Kesulitan dalam Usahatani Komoditas Sayuran (\%)

\begin{tabular}{lccccc}
\hline \multicolumn{1}{c}{ Uraian } & \multicolumn{5}{c}{ Komoditas } \\
\cline { 2 - 6 } & Bw.merah & mentimun & cabai merah & $\begin{array}{c}\text { kembang } \\
\text { kol }\end{array}$ & $\begin{array}{c}\text { Kacang.pa } \\
\text { njang }\end{array}$ \\
\hline $\begin{array}{l}\text { 1. Kesulitan Modal kerja } \\
\text { 2. Kesulitan bibit/benih }\end{array}$ & 100 & 50,00 & 80,00 & 40,00 & - \\
3. Tenaga kerja : & 80,00 & 3,33 & 2,00 & 40,00 & - \\
- pemeliharaan & 0 & 0 & 26,67 & 0 & 0 \\
- panen & 0 & 0 & 33,33 & 0 & 10,00 \\
4. Kesulitan Obat2-an & 20,00 & 0 & 13,33 & 0 & 0 \\
5. Kesulitan Penyimpanan hasil & 40,00 & 50,00 & 60,00 & 20,00 & 0 \\
6. Kesulitan Pemasaran & 0 & 0 & 13,33 & 0 & 0 \\
\hline
\end{tabular}

Sumber : Data Primer 
Tjetjep Nurasa : Meningkatkan Pendapatan Petani Melalui Difersivikasi Tanaman ...

Tabel 3. Analisis Usahatani Padi di Jawa Barat Tahun 2009

\begin{tabular}{|c|c|c|c|c|}
\hline \multirow[t]{2}{*}{ Uraian } & \multirow[t]{2}{*}{ Unit } & \multirow{2}{*}{$\begin{array}{c}\text { Harga/unit } \\
\text { (Rp) }\end{array}$} & \multicolumn{2}{|c|}{ MK1 } \\
\hline & & & Fisik & Nilai (Rp) \\
\hline I. Penerimaan & & & & $14,397,634.00$ \\
\hline Produksi & & & & \\
\hline Utama & $\mathrm{Kg}$ & $2,553.91$ & 5.637 .482 & $14,397,634.00$ \\
\hline Biaya Produksi & $\operatorname{xxxxx}$ & $\operatorname{xxxxx}$ & $\operatorname{xxxxx}$ & $\operatorname{xxxxx}$ \\
\hline 1. Bibit & $\mathrm{Kg}$ & $5,574.10$ & 87.46 & $487,482.85$ \\
\hline 2.Urea & $\mathrm{Kg}$ & $1,359.92$ & 273.26 & $371,606.25$ \\
\hline $3 . \mathrm{ZA}$ & $\mathrm{Kg}$ & $1,258.76$ & 47.12 & $59,318.25$ \\
\hline 4.SP36 & $\mathrm{Kg}$ & $1,741.26$ & 107.93 & $187,938.18$ \\
\hline 5.NPK & $\mathrm{Kg}$ & $2,017.41$ & 101.49 & $204,742.50$ \\
\hline $6 . \mathrm{KCL}$ & $\mathrm{Kg}$ & $2,656.44$ & 8.24 & $21,892.85$ \\
\hline 7.Kandang & $\mathrm{Kg}$ & & & $123,037.23$ \\
\hline 8.Obat-obatan & $\mathrm{Kg}$ & & & $561,419.10$ \\
\hline Total Biaya Produksi ( A) & & & & $2,017,437.22$ \\
\hline Biaya tenaga Kerja & $\operatorname{xxxxx}$ & & & \\
\hline 1.Total TK Pria & HOK & $8,516.45$ & 17.74 & $151,047.83$ \\
\hline 2.Total TK Wanita & HOK & $5,626.47$ & 6.24 & $35,109.20$ \\
\hline Total TK Pra Panen & HOK & & & $186,157.03$ \\
\hline 3.Panen dan Pasca Panen & HOK & & & $2,243,250.00$ \\
\hline Total Biaya Tenaga kerja (B) & & & & $2,429,407.03$ \\
\hline Biaya lainnya & $\operatorname{xxxxx}$ & & & $610,291.44$ \\
\hline 1.Sewa lahan & & & & \\
\hline 2.Pajak & & & & \\
\hline 3.Pompa & & & & \\
\hline 4.BBM & & & & \\
\hline 5.Iuran kas Desa & & & & \\
\hline 6.Zakat hasil bumi & & & & \\
\hline 7. Plastik & & & & \\
\hline 8.tali Rapia & & & & \\
\hline 9.Ajir & & & & \\
\hline 10. lainnya & & & & \\
\hline 11.Mulsa & & & & \\
\hline Total Biaya lainnya ${ }^{\circ}$ & & & & $610,291.44$ \\
\hline Total Biaya A+B+C & & & & $5,057,135.70$ \\
\hline Keuntungan & & & & $9,340,498.30$ \\
\hline R/C Ratio & & & & 2.85 \\
\hline
\end{tabular}




\section{Tjetjep Nurasa : Meningkatkan Pendapatan Petani Melalui Difersivikasi Tanaman ...}

\section{Analisis Usaha Tani Padi}

Usahatani padi di Jawa Barat dan Dari hasil penelitian menunjukkan bahwa hasil produksi padi di Jawa Barat mencapai sekitar 5.6 ton dengan harga jual rata-rata sebesar $\mathrm{Rp} 2,554 / \mathrm{kg}$. Dengan luasan usahatani petani per hektar penerimaan usahatani padi di Jawa Barat mencapai Rp14.4 juta. Sementara biaya total usahatani yang dikeluarkan di Jawa Barat mencapai Rp5.06 juta, dimana proporsi biaya terbesar adalah biaya tenaga kerja yang mencapai Rp2.4 juta atau sekitar 48 persen. Dengan demikian petani padi di Jawa Barat mendapat keuntungan RpRp9.3 juta, sehingga efisiensi usahataninya efisien karena lebih dari satu (1.54). Artinya, dari tiap 1 rupiah biaya yang dikeluarkan, mampu memperoleh pendapatan 1.54 rupiah.

\section{Analisa Usahatani Komoditas Sayuran}

Analisa Usahatani Cabai Merah. Cabai atau cabe merah atau lombok (bahasa Jawa) adalah salah satu komoditas hortikultura yaitu sayuran yang dibutuhkan hampir setiap orang dan memiliki nilai ekonomis yang tinggi. Cabai merupakan tanaman yang mudah ditanam di dataran rendah ataupun di dataran tinggi. Buahnya dapat digolongkan sebagai sayuran maupun bumbu, tergantung bagaimana digunakan. Cabai (Capsicum annum L) merupakan salah satu komoditas sayuran yang banyak dibudidayakan oleh petani di Indonesia karena memiliki harga jual yang tinggi dan memiliki beberapa manfaat kesehatan yang salah satunya adalah zat capsaicin yang berfungsi dalam mengendalikan penyakit kanker. Waktu tanam yang baik untuk lahan kering adalah pada akhir musim hujan (Maret April). Sementara untuk memperoleh harga cabe yang tinggi, penanaman dapat dilakukan pada bulan Oktober dan panen pada bulan Desember, walaupun ada risiko kegagalan.

Salah satu kendala utama dalam sistem produksi cabai di Indonesia adalah adanya serangan lalat buah pada tanaman cabai. Kalshoven, L.G.E. (1981) menerangkan bahwa hama ini sering menyebabkan gagal panen. Dari hasil penelitian menunjukkan bahwa hasil produksi cabe merah yang diperoleh petani adalah sekitar 11.16 ton dengan 6 (enam) kali petik dengan harga jual cabe merah saat itu berkisar antara Rp1,214 sampai Rp13,622/kg. Dengan luasan usahatani petani per hektar penerimaan usahatani cabe merah tersebut mencapai Rp96.96 juta. Sementara biaya total usahatani yang dikeluarkan mencapai Rp169,49 juta, dimana proporsi biaya terbesar adalah biaya tenaga kerja yang mencapai 114.6 juta atau sekitar 67.6 persen. Dengan demikian petani cabe merah mendapatkan kerugian sebesar Rp72.54 juta, sehingga efisiensi usahataninya tidak efisien karena kurang dari satu (0.57). Artinya, dari setiap 1 rupiah biaya yang dikeluarkan, hanya memperoleh pendapatan sebesar 0.57 rupiah. Namun apabila biaya tenaga kerja tidak diperhitungkan dalam usahatani tersebut maka usahatani cabe merah akan mendapatkan keuntungan sebesar Rp42.06 juta, sehingga efisiensi usahataninya menjadi 3.07.

Berdasarkan struktur biayanya, sebagian besar $(67.6 \%)$ biaya usahatani cabe merah ini dialokasikan untuk biaya tenaga kerja yang meliputi biaya tenaga kerja pra panen yang mencapai Rp55 juta atau sekitar 32 persen dari biaya total serta biaya panen dan pasca panen yang mencapai Rp59.59 juta atau sekitar 35 persen. Sementara alokasi biaya lainnya adalah biaya produksi seperti untuk bibit, pupuk dan obat-obatan mencapai Rp31.62 juta atau sekitar 18.65 persen serta biaya lainnya (sewa lahan, pajak, dan lainnya) yang mencapai Rp23.27 juta atau sekitar 13.7 persen.

Analisa Usahatani Ketimun. Tanaman ketimun merupakan salah satu komodias yang ditanam tersebar dan seringkali masih kurang diperhatikan tidak seperti tanaman palawija lainnya. Tetapi saat ini kegiatan hortikultura dalam mengais omset komoditas ini baik itu petani, pedagang dan perusahaan untuk menyumbang sangat besar omset yang diinvestasikan di pertanian khususnya hortikultura. Karena keuntungan yang diterima petani sebagai produsen cukup stabil. Pengembangan ketimun dikabupaten Karawang relatif cukup lama hingga saat ini, pemasarannya pun tidak mengalami kesulitan. Ketimun dari Karawang hampir $80 \%$ dipasarankan ke Jakarta, Bogor sekitarnya. 
Tjetjep Nurasa : Meningkatkan Pendapatan Petani Melalui Difersivikasi Tanaman ...

Tabel 4. Usahatani Cabai Merah Tahun 2009

\begin{tabular}{|c|c|c|c|c|}
\hline Uraian & Unit & Harga/unit & & MK1 \\
\hline & & (Rp) & Fisik & Nilai (Rp) \\
\hline \multicolumn{5}{|l|}{ I. Penerimaan } \\
\hline Produksi & $\mathrm{Kg}$ & 8688.98 & 11158.49 & $96,955,898.00$ \\
\hline Biaya Produksi & $\operatorname{xxxxx}$ & $\operatorname{xxxxx}$ & $\operatorname{xxxxx}$ & $\operatorname{xxxxx}$ \\
\hline 1. Bibit & $\mathrm{Kg}$ & & & $1,473,704.00$ \\
\hline 2.Urea & $\mathrm{Kg}$ & & & $91,396.83$ \\
\hline $3 . \mathrm{ZA}$ & $\mathrm{Kg}$ & & & $133,341.50$ \\
\hline 4.SP36 & $\mathrm{Kg}$ & & & $304,409.50$ \\
\hline 5.NPK & $\mathrm{Kg}$ & & & $2,269,953.00$ \\
\hline $6 . \mathrm{KCL}$ & $\mathrm{Kg}$ & & & $440,050.50$ \\
\hline 7.Kandang & $\mathrm{Kg}$ & & & $478,869.00$ \\
\hline 8.Kompos & $\mathrm{Kg}$ & & & $800,000.00$ \\
\hline 9. Organik & $\mathrm{Kg}$ & & & $369,365.10$ \\
\hline 10.Pupuk Lainnya & & & & $2,415,761.00$ \\
\hline 11. Obat-obatan & & & & $22,843,957.00$ \\
\hline Total Biaya Produksi ( A) & & & & $31,620,807.43$ \\
\hline Biaya tenaga Kerja & $\operatorname{xxxxx}$ & & & \\
\hline 1.Pembibitan & HOK & $6,153.85$ & 32.1 & $197,538.59$ \\
\hline 2.Pengolahan Tanah & HOK & $26,593.41$ & 123.34 & $3,280,031.19$ \\
\hline 3. Persiapan tanam & $\mathrm{HOK}$ & $60,034.01$ & 195.98 & $11,765,465.28$ \\
\hline $\begin{array}{l}\text { 3.cabut bibit,Tanam } \\
\text { 4.Pemeliharaan }\end{array}$ & $\begin{array}{l}\mathrm{HOK} \\
\mathrm{HOK}\end{array}$ & $\begin{array}{l}30,000.00 \\
64,190.48\end{array}$ & $\begin{array}{r}53.58 \\
594.42\end{array}$ & $\begin{array}{r}1,607,400.00 \\
38,156,105.12\end{array}$ \\
\hline Total TK Pra Panen & HOK & $339,741.70$ & 999.42 & $55,006,540.18$ \\
\hline 7.Panen & $\mathrm{HOK}$ & $6,000.00$ & 174.75 & $59,369,862.08$ \\
\hline 8.Pasca Panen & HOK & & 37.7 & $226,200.00$ \\
\hline Total Biaya Tenaga kerja (B) & & & & $114,602,602.25$ \\
\hline $\begin{array}{l}\text { Biaya lainnya } \\
\text { 1.Sewa lahan } \\
\text { 2.Pajak } \\
\text { 3.Pompa } \\
\text { 4.BBM } \\
\text { 5.Iuran kas Desa } \\
\text { 6.Zakat hasil bumi } \\
\text { 7. Plastik }\end{array}$ & $\mathrm{xxxxx}$ & & & $\begin{array}{r}3,314,286.00 \\
50,416.67 \\
100,000.00 \\
965,007.20 \\
50,000.00 \\
601,515.20 \\
3,133,647.00\end{array}$ \\
\hline $\begin{array}{l}\text { 8.tali Rapia } \\
\text { 9.Ajir } \\
\text { 10. lainnya }\end{array}$ & & & & $\begin{array}{r}790,373.40 \\
304,742.00 \\
13,563,472.00\end{array}$ \\
\hline 11.Mulsa & & & & $400,000.00$ \\
\hline Total Biaya lainnya ${ }^{\circ}$ & & & & $23,273,459.47$ \\
\hline Total Biaya A+B+C & & & & $169,496,869.15$ \\
\hline Keuntungan & & & & $(72,540,971.15)$ \\
\hline R/C Ratio & & & & $\mathbf{0 . 5 7}$ \\
\hline
\end{tabular}




\section{Tjetjep Nurasa : Meningkatkan Pendapatan Petani Melalui Difersivikasi Tanaman ...}

Menanam ketimun diperlukan curah hujan yang cukup banyak dan umumnya di wilayah jawa barat ditanam peterngahan tahun menjelang hujan datang . Di Karawang tanaman ketimun umumnya ditanam dengan cara sederhana dan penggunaan saprodi belum seintensif seperti tanaman hortikultura lainnya. Perawatan ketimun tergantung pada musim terutama dimusim hujan hasil lebih baik dibanding musim kemarau. Bila ketimun diusahakan dengan lebih baik, akan dapat menghasilkan 50 ton perhektar.

Sebagai perbandingan pada Tabel 5 . dijelaskan analisis usahatani ketimun bahwa produksi yang dihasilkan mencapai 15 ton dengan harga jual Rp2300/Kg hingga Rp2500/Kg. Sehingga pendapatan yang diterima sekitar Rp34.5 juta/ha. Dan keuntungan yang diperoleh sekitar Rp10.2 juta perhektar. Dalam usaha ketimun biaya yang relatif besar ada pada penggunaan obat-obatan seperti obat Grower (semacam obat perang tumbuh) bisa mencapai Rp900.000/Ha. Dari pendapatan sekitar Rp34.5 juta/ha dan total biaya yang dikeluarkan mencapai hampir $69 \%$ dan mendapatkan keuntungan yang tinggi yakni sekitar Rp10.1 juta rupiah/ha.

Ketimun sebagai tanaman pesaing padi di wilayah Jawa Barat khususnya kabupaten Karawang, relatif masih rendah bagi petani yang membudidayakan, nampaknya yang membudidayakan tanaman ini petani yang memiliki modal lebih dari cukup. Ketimun yang dihasilkan produksinya masih rendah paling tidak diwilayah dataran rendah minimal 25 ton perhektar. Umur ketimun yang diusahakan lamanya antara 2,5 bulan sampai 3 bulan. Nampaknya dalam satu musim, ketimun dapat ditanam 2 kali tanam bila cukup intensif. Di karawang usaha ketimun khususnya pada penggunaan tenaga kerja pengolahan tanah cenderung diborongkan dan sedikit tenaga dalam keluarga yang ikut serta mulai tanam hingga panen. Lebih rinci usahatani ketimun dapat dilihat pada Tabel 5 .

Tabel 5. Usahatani Ketimun per Ha di Kabupaten Karawang pada MK1 Tahun 2009

\begin{tabular}{|c|c|c|c|c|c|}
\hline & \multirow{2}{*}{ Uraian } & \multirow{2}{*}{ Unit } & \multirow{2}{*}{$\begin{array}{c}\text { Harga/un } \\
\text { it } \\
(\mathrm{Rp}) \\
\end{array}$} & \multicolumn{2}{|c|}{ MK1 } \\
\hline & & & & Fisik & Nilai (Rp) \\
\hline $\mathrm{I}$ & I. Penerimaan & & & & \\
\hline \multirow[t]{16}{*}{ A } & Produksi & $\mathrm{Kg}$ & 2300 & 15000 & 34500000 \\
\hline & Biaya Produksi & $\operatorname{xxxxx}$ & $\operatorname{xxxxx}$ & $\operatorname{xxxxx}$ & $\operatorname{xxxxx}$ \\
\hline & 1. Bibit & $\mathrm{Kg}$ & 350000 & 0.94 & 329000 \\
\hline & 2.Urea & $\mathrm{Kg}$ & 1200 & 49.54 & 59448 \\
\hline & $3 . \mathrm{ZA}$ & $\mathrm{Kg}$ & & & 0 \\
\hline & 4.SP36 & $\mathrm{Kg}$ & 1200 & 49.54 & 59448 \\
\hline & 5.NPK & $\mathrm{Kg}$ & 2400 & 165.34 & 396816 \\
\hline & 6.KCL & $\mathrm{Kg}$ & & & 0 \\
\hline & 7.Kandang & $\mathrm{Kg}$ & 150 & 2000 & 300000 \\
\hline & 8.Kompos & $\mathrm{Kg}$ & 1000 & 93.78 & 93780 \\
\hline & 9. Organik & $\mathrm{Kg}$ & 9000 & 33.33 & 299970 \\
\hline & 10.Pupuk Cair & & & & 0 \\
\hline & 11. rock pospat & & 1700 & 107.34 & 182478 \\
\hline & 12.pupuk lainnya & & 9000 & 100 & 900000 \\
\hline & 13. Obat-obatan & & & & 0 \\
\hline & Total Biaya Produksi ( A) & & & & 3910160 \\
\hline \multirow[t]{8}{*}{$\mathrm{B}$} & Biaya tenaga Kerja & $\operatorname{xxxxx}$ & $\operatorname{xxxxx}$ & $\operatorname{xxxxx}$ & $\operatorname{xxxxx}$ \\
\hline & 1.Pembibitan & $\mathrm{HOK}$ & 33000 & 20.3 & 669900 \\
\hline & 2.Pengolahan Tanah & HOK & & & 732275 \\
\hline & 3. Persiapan tanam & $\mathrm{HOK}$ & 50000 & 15.56 & 778000 \\
\hline & 3.cabut bibit,Tanam & $\mathrm{HOK}$ & 50000 & 19.18 & 959000 \\
\hline & 4.Menyiang,pembumbunan,pemupukan & $\mathrm{HOK}$ & 25000 & 130 & 3250000 \\
\hline & 5.Penyemprotan & HOK & & & 0 \\
\hline & 6. Penyiraman & $\mathrm{HOK}$ & & & 0 \\
\hline
\end{tabular}


Tjetjep Nurasa : Meningkatkan Pendapatan Petani Melalui Difersivikasi Tanaman ...

\begin{tabular}{|c|c|c|c|c|c|}
\hline \multicolumn{2}{|c|}{ Total TK Pra Panen } & \multirow{3}{*}{ HOK } & 25000 & 185.04 & 6389175 \\
\hline & 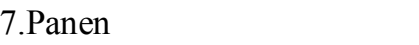 & & 25000 & 143.14 & 3578500 \\
\hline & Total Biaya Tenaga kerja (B) & & & & 9967675 \\
\hline $\mathrm{C}$ & Biaya lainnya & xxxxx & xxxxx & xxxxx & xxxxx \\
\hline & 1.Sewa lahan & & & & 4940476 \\
\hline & 2.Sewa Pompa air & & & & 0 \\
\hline & 3.Pajak Sawah & & & & 64727 \\
\hline & 4.iuran irigasi & & & & 0 \\
\hline & 5.Iuran kas Desa & & & & 0 \\
\hline & 6.Zakat hasil bumi & & & & 0 \\
\hline & 7. Plastik & & & & 80000 \\
\hline & 8.tali Rapia & & & & 49504 \\
\hline & 9.Ajir & & & & 69587 \\
\hline & 10. lainnya & & & & 5262081 \\
\hline $\mathrm{D}$ & Total Biaya lainnya (C) & & & & 10466375 \\
\hline $\mathrm{E}$ & Total Biaya $A+B+C$ & & & & 24344210 \\
\hline $\mathrm{F}$ & Keuntungan & & & & 10155790 \\
\hline G & R/C Ratio & & & & 1.42 \\
\hline
\end{tabular}

Sumber: Data primer diolah

Dari hasil usaha yang dilakukan total biaya yang dikeluarkan mencapai $69 \%$ dari pendapatan yang diterima dengan total produksi yang didapat sekitar 15 ton. Dari hasil pendapatan yang diperoleh, petani mengorbankan total biaya khususnya saprodi sebesar Rp391 ribu rupiah perhektar, sedangkan korbanan pada biaya tenaga kerja mencapai Rp900 ribu lebih perhektar. Pengeluaran biaya tenaga kerja nampaknya yang cukup besar pengorbanan petani ada pada aspek kegiatan pemeliharaan seperti Penyiangan, pembumbunan dan pemupukan.

Analisa Usahatani Bawang Merah. Bawang merah merupakan salah satu komoditas hortikultura yang mendapat prioritas pengembangan sejak pelita IV. (Direktorat Jenderal Tanaman Pangan, 1990).Sejak dulu produktivitas bawang selalu mengalami peningkatan, namun produktivitas ini masih belum mencukupi permintaan di dalam negeri., sehingga untuk mencukupi kebutuhan bawang merah di dalam negeri pemerintah harus mengimpor. Upaya untuk meningkatan produksi bawang merah memerlukan dukungan berupa regionalisasi dan konsolidasi dari sentra-sentra produksi yang ada dengan didasari oleh keunggulan komparatif dan kompetitif daerah produksi. Persoalannya adalah penggunaan sumberdaya yang terbatas seperti lahan dan modal harus diusahakan seefisien mungkin.

Bawang merah sudah cukup lama dikembangkan di kabupaten Indramayu, ragam penggunaan pola tanam dan orientasi perdagangan yang digunakan turut berperan terhadap keberhasilan pengembangan bawang merah di Indramayu. Dengan pemilihan sistem usahatani dan orientasi perdagangan bawang merah yang tepat dapat meningkatkan produktivitas di dalam negeri dan pendapatan petani dapat terjamin. Untuk melihat perdagangan berorientasi ekspor yang memadai, tentunya terlebih dahulu mempelajari analisa usahataninya. Dalam setiap analisis usahatani biasanya dibedakan biaya variable yaitu; biaya yang dikeluarkan untuk membeli sarana produksi dan biaya tenaga kerja, serta biaya tetap seperti biaya sewa lahan dan pajak. $\mathrm{Hal}$ ini akan menjadi pertimbangan untuk menunjukkan besarnya penerimaan yang diperoleh dari setiap rupiah yang dikeluarkan.

Analisa usahatani komoditas bawang merah di kabupaten Indramayu dapat dilihat pada Tabel 6. berikut ini. Dalam usahatani bawang merah di Indramayu bahwa total biaya produksi yang dikeluarkan petani untuk luas garapan satu hektar adalah Rp33 juta dan keuntungan yang diperoleh sebesar Rp26 juta rupiah. Dalam satu musim produksi bawang merah yang didapat mencapai 13 ton dengan harga yang normal yang tidak terlalu tinggi yakni sekitar Rp4600 rupiah $/ \mathrm{kg}$. Biasanya harga bawang, dan komoditas sayuran lainnya akan sangat tinggi harga jual saat menjelang hari raya dan menjelang puasa. 
Tjetjep Nurasa : Meningkatkan Pendapatan Petani Melalui Difersivikasi Tanaman ...

Tabel 6. Usahatani Bawang Merah per Ha di Kabupaten Indramayu MK1 Tahun 2009

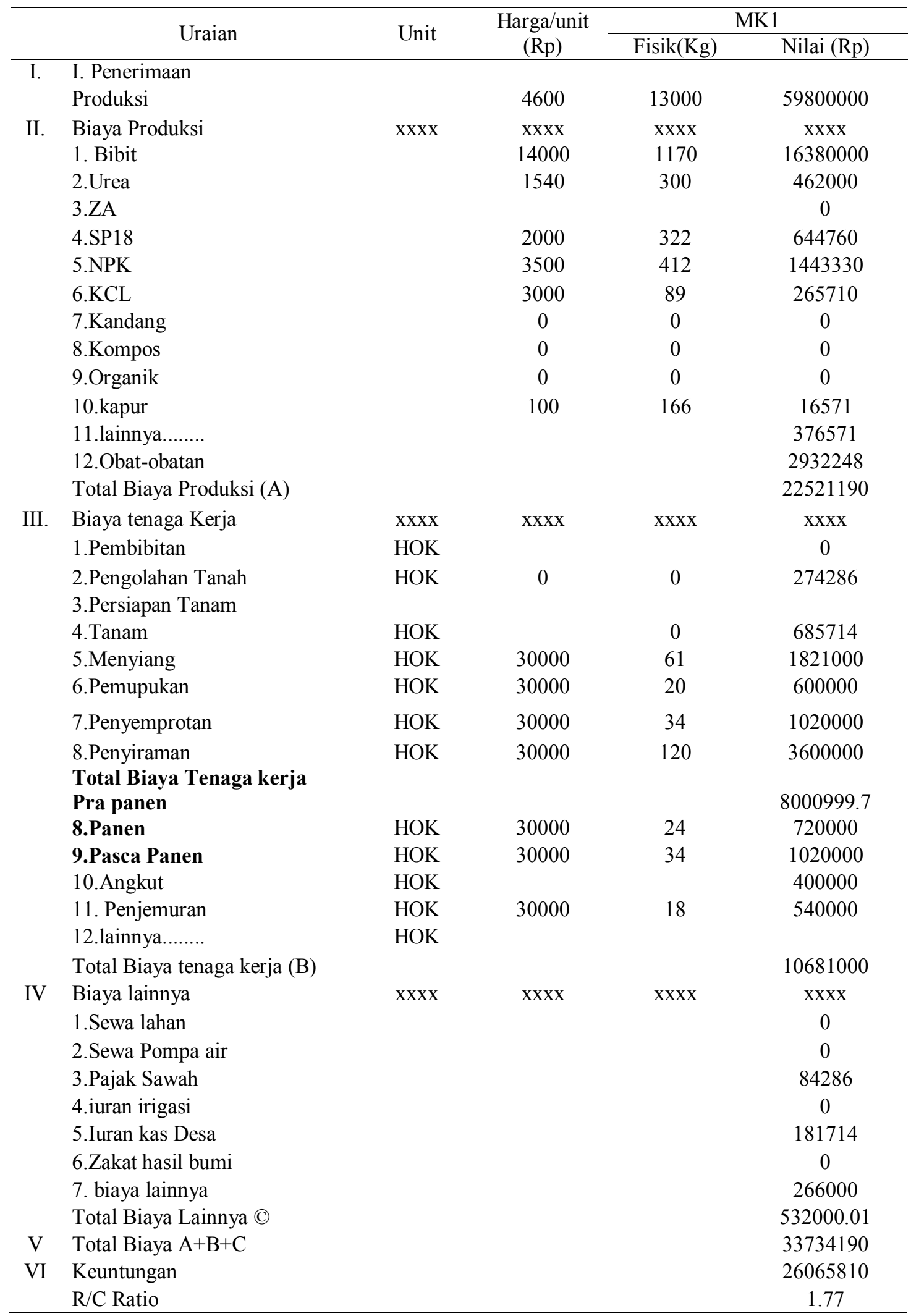

Sumber: Data primer diolah. 


\section{Tjetjep Nurasa : Meningkatkan Pendapatan Petani Melalui Difersivikasi Tanaman ...}

Hal ini sudah menjadi polemik bagi masyarakat dengan adanya kenaikan harga sayuran yang sukar dikendalikan oleh instansi terkait. Dari Tabel 6. tersebut total biaya yang dikeluarkan petani ada pada sarana produksi terutama biaya bibit dan obat-obatan (Rp1.6 juta rupiah dan 225 ribu rupiah). Sedangkan untuk biaya tenaga kerja, besaran biaya yang dikeluarkan pada kegiatan pra panen mencapai Rp8 juta rupiah perhektar. Dengan demikian biaya total untuk penggunaan tenaga kerja sekitar Rp10 juta rupiah perhektar.

Analisa Usahatani Kembang KOL. Kol bunga putih merupakan tanaman sayur famili Brassicaceae (jenis kol dengan bunga putih kecil) berupa tumbuhan berbatang lunak. Masyarakat di Indonesia menyebut kubis bunga sebagai kol kembang atau blumkol (berasal dari bahasa Belanda Bloemkool). Walaupun tanaman ini adalah tanaman dataran tinggi triopka dan wilayah dengan lintang lebih tinggi, beberapa kultivar dapat membentuk bunga di dataran rendah sekitar khatulisiwa. Daerah dataran tinggi (pegunungan) adalah pusat budidaya kubis bunga. Pusat Produksi tanaman ini terletak di Jawa Barat yaitu di Lembang, Cisarua, Cibodas dan Indramayu.

Di Indonesia, kubis bunga termasuk salah satu sayuran yang dikonsumsi oleh kalangan terbatas karena harganya yang relatif lebih tinggi daripada sayuran lainnya. Budi daya tanaman kubis bunga dalam skala yang lebih besar agaknya cukup menjanjikan mengingat saat ini Indonesia sudah mengekspor bunga kol ke Hongkong, Jepang, Singapura dan Brunei. Nilai gizi yang dikandung kubis bunga dapat dikatakan istimewa terutama kandungan mineralnya. Dengan demikian sayuran ini dapat menarik perhatian konsumen terutama dari kalangan menengah atas yang telah sadar akan arti kualitas makanan. (Rukmana, Rahmat.1994)

Tanaman kembang kol biasanya ditanam di dataran tinggi, namun para petani di Kabupaten Indramayu melihat peluang untuk bertanam kembang kol, meski tinggal di dataran rendah, merekapun beralih dari menanam padi menjadi petani kembang kol, karena saat ini peluang usaha kembang kol kini cukup menjanjikan. Para petani di sejumlah daerah di Kabupaten Indramayu mulai beralih dari tanaman padi ke budidaya tanaman kembang kol. Hal ini disebabkan keuntungan yang diperoleh lebih besar ketimbang menanam padi. Budidaya kembang kol ini baru dilakukan petani di Desa Sumuradem, Kecamatan Sukra namun minat pedagang di Pasar Induk Cibitung maupun Kramat Jati Jakarta sangat besar untuk membeli kembang kol dataran rendah. Terlebih, pangsa pasar ekspor ke Australia dan Singapura sangat terbuka untuk produk ini. Disisi lain kelebihannya kembang kol yang ditanam di dataran rendah tidak mudah busuk dan rasanya manis. Dari segi harga, kembang kol di sini tidak berbeda dengan kembang kol yang ditanam di dataran tinggi yakni 6 ribu rupiah perkilogram.

Dari uraian diatas, tim mempelajari serta mewawancarai petani kembang kol bagaimana perkembangan usahatani kembang kol selama satu musim tanam di kabupaten Indramayu yang tertera dalam Tabel 7 . berikut ini. Tanaman kembang kol tidak jauh berbeda dengan budidaya tanaman kubis atau tanaman kol. Tanaman ini masa panennya sekitar 55 hari - 100 hari dan produksinya dapat mencapai 12 ton hingga 14 ton/ha, dengan lokasi ketinggian 400 - 2000 m dpl. (Wahyudi. 2010).

Pengusahaan tanaman kembang kol di Indramayu yang ditanam secara monokultur. Dari hasil analisis yang didapat dari wawancara petani, nampaknya prospek tanaman dari orientasi perdagangannya cukup menjanjikan kedepannya, karena baik dari segi perdagangan antar daerah secara ekonomi menguntungkan. Adapun hasil analisa usahatani kembang kol tertera pada Tabel 7.

Pendapatan usahatani kembang kol selama satu musim tanam perhektar sekitar Rp36 juta per hektar, dengan korbanan total biaya yang dikeluarkan sebesar Rp17.4 juta rupiah. Input biaya yang terbesar ada pada aspek tenaga kerja, yang mencapai Rp8.94 juta rupiah, terutama pada kegiatan pra panen seperti pemeliharaan. Secara keseluruhan total biaya yang dikeluarkan tersebut, petani masih mendapatkan keuntungan yang sangat tinggi yakni sekitar 18juta rupiah perhektar dengan $\mathrm{R} / \mathrm{C}$ sebesar 1.80 . Nampaknya pengembangan usahatani kembang kol sangat prospek kedepannya, dan perlu dikembangkan lebih luas lagi, sehingga kesejahteraan petani akan lebih terjamin lagi. 
Tjetjep Nurasa : Meningkatkan Pendapatan Petani Melalui Difersivikasi Tanaman ...

Tabel 7. Usahatani Kembang Kol per Ha di Kabupaten Indramayu pada MK1 2009

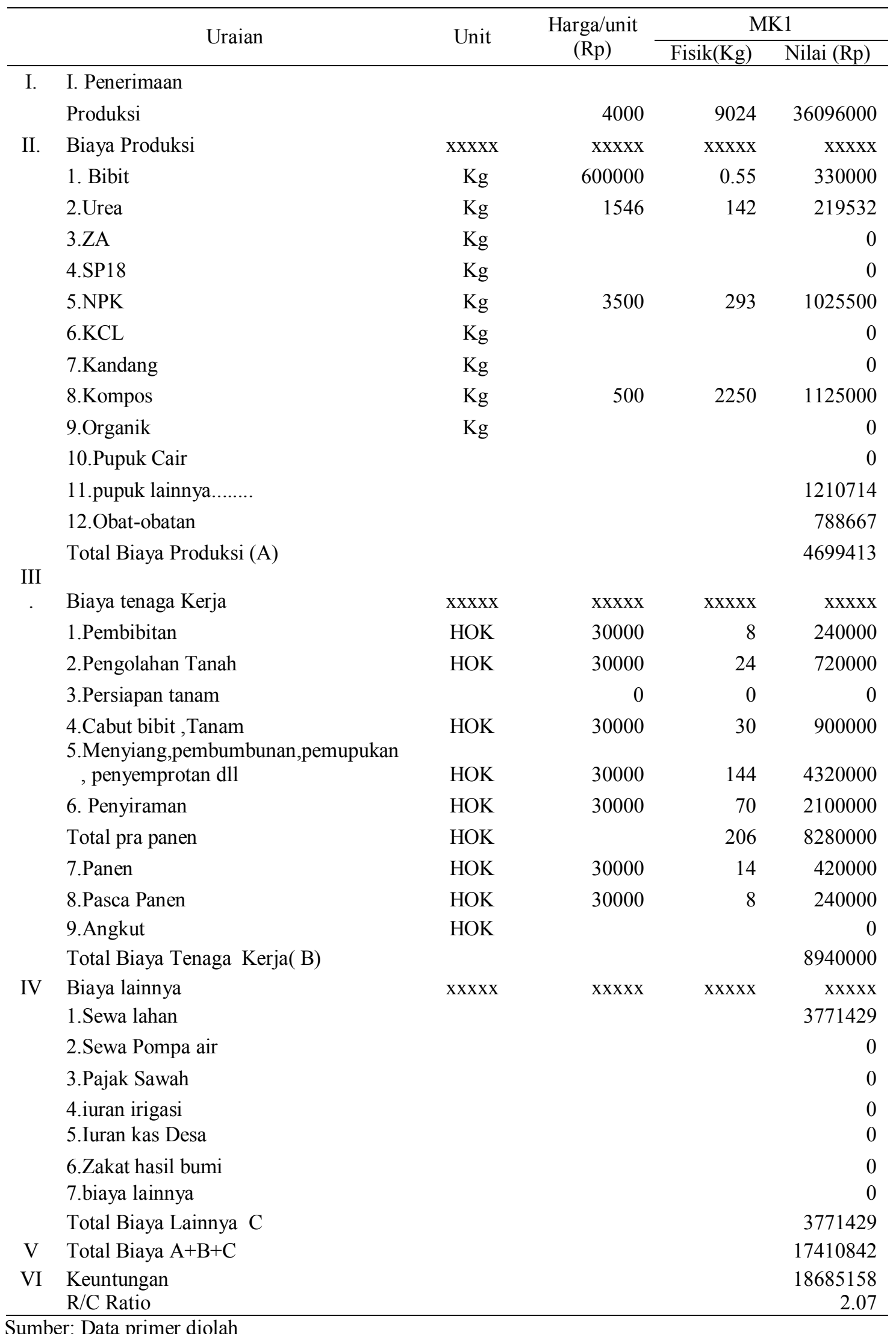




\section{Tjetjep Nurasa : Meningkatkan Pendapatan Petani Melalui Difersivikasi Tanaman ...}

Analisa Usahatani Kancang Panjang. Kacang Panjang merupakan salah satu jenis sayuran yang banyak dikonsumsi oleh masyarakat. Tanaman sayur ini mudah dibudidayakan. Kacang Panjang tidak memilih tempat khusus untuk pertumbuhannya, dapat diusahakan hampir setiap jenis tanah. Tetapi untuk mendapatkan hasil yang maksimum, penanaman lebih baik dilakukan pada lahan yang sesuai dengan kebutuhan ekologi tanaman tersebut. (Eko Haryanto, dkk. 2010).

Dalam membudidayakan sayuran tanaman kacang panjang ada beberapa faktor yang perlu mendapat perhatian agar produksi yang diharapkan dapat tercapai. Faktor tersebut antara lain penggunaan benih unggul, pengolahan tanah, pengairan, pemupukan, serta pengendalian hama dan penyakit.
Panen merupakan saat yang dinantikan petani sebagai perwujudan keberhasilan dalam melakukan budidaya kacang panjang. Pada tanaman kacang panjang yang sehat dan tumbuh subur dikabupaten Karawang dapat menghasilkan produksi berkisar 13,6 ton/ha (Tabel 8). Dari analisa usahatani kacang panjang pada Tabel 8, bahwa Rata-rata biaya/usahatani/musim yang dikeluarkan sebesar Rp23.2 juta rupiah, yang terdiri dari biaya saparodi sebesar Rp6.34 juta rupiah, biaya tenaga kerja $\mathrm{Rp} 7.35$ juta dan biaya lainnya Rp9.5 juta rupiah. Dari biaya tersebut biaya yang paling banyak dikeluarkan yakni sebesar RpRp9.5 juta adalah biaya lainnya /musim tanam.

Tabel 8. Usahatani Kacang Panjang per Ha di Kabupaten Karawang pada MK1 Tahun 2009

\begin{tabular}{|c|c|c|c|c|c|}
\hline & \multirow[t]{2}{*}{ Uraian } & \multirow[t]{2}{*}{ Unit } & \multirow{2}{*}{$\begin{array}{l}\text { Harga/unit } \\
\text { (Rp) }\end{array}$} & \multicolumn{2}{|c|}{ MK1 } \\
\hline & & & & Fisik(Kg) & Nilai (Rp) \\
\hline \multirow[t]{2}{*}{ I. } & I. Penerimaan & & & & \\
\hline & Produksi & & 2700 & 13619,32 & 36772164 \\
\hline \multirow[t]{15}{*}{ II. } & Biaya Produksi & $\operatorname{xxxxx}$ & $\operatorname{xxxxx}$ & $\operatorname{xxxxx}$ & $\operatorname{xxxxx}$ \\
\hline & 1. Bibit & $\mathrm{Kg}$ & 25600 & 20 & 512000 \\
\hline & 2.Urea & $\mathrm{Kg}$ & 1500 & 100 & 150000 \\
\hline & $3 . \mathrm{ZA}$ & $\mathrm{Kg}$ & & & 0 \\
\hline & 4.SP18 & $\mathrm{Kg}$ & 2000 & 100 & 200000 \\
\hline & 5.NPK & $\mathrm{Kg}$ & 2500 & 138 & 343750 \\
\hline & 6.KCL & $\mathrm{Kg}$ & & & 0 \\
\hline & 7.Kandang & $\mathrm{Kg}$ & & & 0 \\
\hline & 8.Kompos & $\mathrm{Kg}$ & 500 & 2160 & 1080000 \\
\hline & 9. Organik & $\mathrm{Kg}$ & & & 0 \\
\hline & 10.Pupuk Cair & & & & 0 \\
\hline & 11.dolomit........ & & 500 & 433 & 216665 \\
\hline & 12.Obat-obatan & & & & 2000000 \\
\hline & 13.pupuk lainnya & & & & 1845111 \\
\hline & Total Biaya produksi (A) & & & & 6347526 \\
\hline \multirow[t]{11}{*}{ III. } & Biaya tenaga Kerja & $\operatorname{xxxxx}$ & $\operatorname{xxxxx}$ & & \\
\hline & 1.Pembibitan & & & & 0 \\
\hline & 2.Pengolahan Tanah & & & & 1500000 \\
\hline & 3.Persiapan Tanam & $\mathrm{HOK}$ & 25000 & 30 & 750000 \\
\hline & 4.Tanam & HOK & 25000 & 30 & 750000 \\
\hline & 5.Menyiang,pembumbunan, dll & HOK & 30000 & 50 & 1500000 \\
\hline & 6.Penyemprotan & HOK & 25000 & 12 & 300000 \\
\hline & 7.Menyiram & HOK & 25000 & 12 & 300000 \\
\hline & Total Prapanen & & & & 5100000 \\
\hline & 8.Panen & HOK & 25000 & 90 & 2250000 \\
\hline & Total Biaya Tenaga kerja (B) & & & & 7350000 \\
\hline \multirow[t]{2}{*}{ IV } & Biaya lainnya & $\operatorname{xxxxx}$ & $\operatorname{xxxxx}$ & $\operatorname{xxxxx}$ & $\operatorname{xxxxx}$ \\
\hline & 1.Sewa lahan & & & & 4252000 \\
\hline
\end{tabular}


Tjetjep Nurasa : Meningkatkan Pendapatan Petani Melalui Difersivikasi Tanaman ...

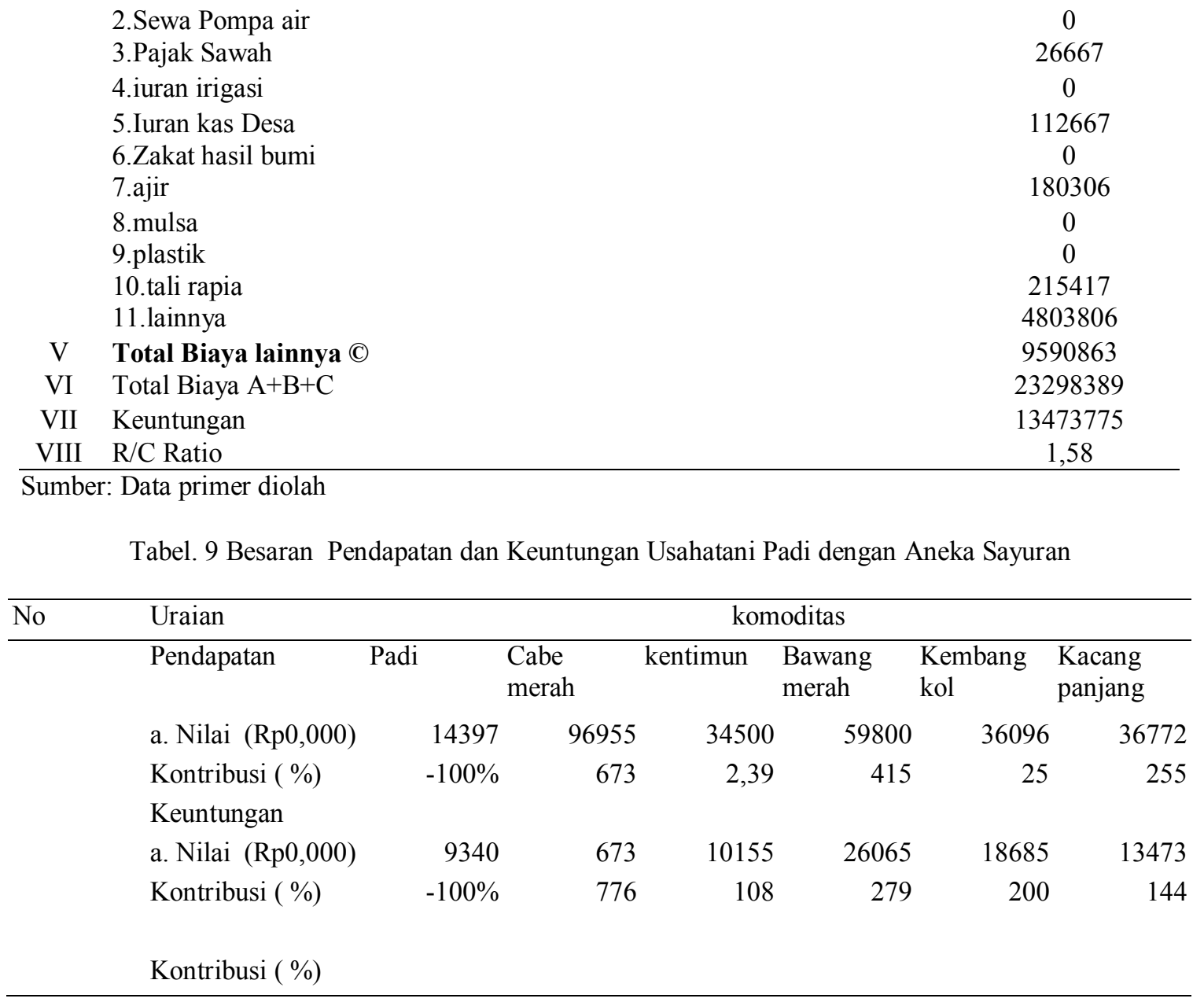

Pada aspek Tenaga kerja terutama pada kegiatan pra panen biaya paling besar terhadap kegiatan tenaga kerja. Dari total biaya yang dikeluarkan keuntungan yang diterima sangat besar yakni sekitar Rp13.4 juta dengan R/C sebesar 1,58. Jadi dalam hal temuan hasil penelitian, nampaknya pengembangan usahatani kacang panjang di Karawang sangat mendukung dalam pengembangan pertanian khususnya hortikultura, paling tidak pada instansi terkait, dan lembaga swasta. Sehingga komoditas kacang panjang menjadi komoditas unggulan daerah. Pendapatan dan keuntungan usahatani aneka sayuran dan padi disajikan pada Tabel 9 .

Dilihat dari segi pendapatan usahatani padi dibandingkan dengan usahatani aneka sayuran menunjukan, bahwa pendapatan usahatani aneka sayuran lebih tinggi dari pendapatan usahatani padi, terutama pada cabe merah (673 \%), bawang merah (415\%), sedangkan berdasarkan tingkat keuntungan usahatani aneka sayuran lebih tinggi dibandingkan dengan keuntungan usahatani padi, terutama cabe merah (776\%), bawang merah (279 \%) kembang kol (200 \%) dan kacang panjang (144\%), walaupun untuk kacang panjang dan ketimun tingkat keuntungannya lebih kecil dari komoditas sayuran yang lain tapi tingkat keuntungnya masih lebih baik. Kondisi ini kecenderungannya tidak berbeda jauh dengan usahatani padi, karena biaya yang dikeluarkan ada usahatani kacang panjang dan ketimun lebih besar dari usahatani padi

\section{SIMPULAN}

Analisa usahatani untuk komoditas hortikultura (sayuran) seperti Timun, Bawang Merah, Kacang panjang, Kembang Kol, masih sangat menguntungkan diusahakan di lahan sawah dalam musim yang bersamaan dengan tanaman padi, adapun keuntungan perhektar dari masing-masing komoditas adalah sekitar Rp10,15 juta, Rp26,06 juta, Rp13,47 juta, 


\section{Tjetjep Nurasa : Meningkatkan Pendapatan Petani Melalui Difersivikasi Tanaman ...}

Rp18,69 juta). Dengan R/C masing-masing komoditas adalahketimun ( R/C 1.42), Bawang Merah R/C 1.77, Kacang panjang R/C 1,58, kembang Kol R/C 2.07. Pada lima komoditas difersifikasi dengan padi, paling tidak ada perbaikan dalam kebijakan harga jual petani atau kebijakan harga output dapat diambil oleh pemerintah, karena merupakan insentif yang signifikan untuk menjadikan usahatani yang lebih menguntungkan. Fasilitas kredit maupun subsidi input sangatlah diperlukan oleh petani agar usahataninya menjadi layak dan lebih menguntungkan. Untuk cabe merah dalam negeri sudah mendekati harga dunia. Tetapi beberapa bulan terkahir ini harga cabe merah sudah tidak rasional lagi, karena jauh melebihi harga dunia, dan itupun sudah meresahkan masyarakat, pedagang dan pihak yang berkepentingan didalamnya. Disisi laing dengan permintaan dalam negeri yang cukup besar, konsumsi dalam negeri pun harus bersaing dengan ekspor, namun ekspor cabe merah masih dapat dikatakan kurang, dari berbagai aspek terkait seperti cuaca yang saat ini kurang baik, serta input yang masih rendah. Walaupun tetapi insentif harga masih sangat diperlukan dan Pemerintah dapat mengupayakan perluasaan negara tujuan ekspor, tidak hanya terpaku pada satu tujuan utama. Untuk itu untuk seluruh komoditas difersifikasi padi tetap dapat dipertahankan dan dikembangkan lebih luas lagi dan lebih kompetitif dimasa-masa mendatang.

Upaya pengembangan produk pangan (sayuran) dalam negeri melalui pengembangan komoditas difersifikasi padi, bukan hanya terpaku pada penyediaan lahan semata, namun aspek lain yang perlu mendapatkan perhatian pengambil kebijakan adalah mencermati indikator perdagangan, Dengan adanya peluang ekspor yang lebih luas sesuai permintaan pasar dunia, pemanfaatan terjadinya hal tersebut dapat ditangkap dan diberdayakan ke petani, sehingga kesejahteraan masyarakat tani Indonesia lebih terjamin.

\section{DAFTAR PUSTAKA}

Adnyana, M.O, Sumaryanto, M. Rachmat, R. Kustiari, SH. Susilowati, E. Suryani and Suprapto. 2000. Assesing the Rural Development Impact of the Crisis in
Indonesia. CASER, Bogor, Indonesia and The World Bank, Washington D.C.

Hadi, P.U., C. Saleh, A. S. Bagyo, R. Hendayana, Y. Marisa, dan I. Sadikin. 2000. Studi Kebutuhan Asuransi Pertanian Pada Pertanian Rakyat. Laporan Penelitian, Pusat Penelitian Sosial Ekonomi Pertanian, Bogor.

Handewi P. Saliem dan Supriyati 2000 Pusat Analisis Sosial Ekonomi dan Kebijakan Pertanian, Diversifikasi Usahatani Dan Tingkat Pendapatan Petani Di Lahan Sawah

Pakpahan, A. 1989. Refleksi Diversifikasi Dalam Teori Ekonomi. Makalah disampaikan pada Kongres dan Konpernas IX Perhepi, Jakarta 12-16 Januari 1989. Perhimpunan Ekonomi Pertanian Indonesia (PERHEPI). Jakarta

Petit, M. and S. Barghouti. 1992. Diversification: Challenges and Opprotunities, In: S. Barghouti, L. Garbus, and D. Umali (Eds). Trends in Agricultural Diversification: Regional Perspectives. World Bank Technical Paper No. 180. World Bank, Washington, D.C.

Rachman, H.P.S., dan Supriyati 2003. Catatan Lapangan Survei Prospek Diversifikasi Usaha di lahan Sawah di Kabupaten Ngawi. (Tidak dipublikasikan).

Saliem, H. P. dan Supriyati. 2006. Diversifikasi Usahatani dan Tingkat Pendapatan Petani di Lahan Sawah. dalam: Suradisastra et al. (Penyunting). Diversifikasi Usahatani Dan Konsumsi: Suatu Alternatif Peningkatan Kesejahteraan Rumah Tangga Petani. Monograph Series No. 27. Pusat Analisis Sosial Ekonomi dan Kebijakan Pertanian, Bogor.

Sarasutha, IGP dan M.N. Noor. 1994. Alternatif Penanggulangan Kemiskinan dengan Pendekatan Agroekosistem di Kawasan Timur Indonesia. Suatu Tinjauan Hasil Penelitian. Dalam: Kinerja Penelitian Tanaman Pangan. Buku 6. SistemUsahatani dan Komponen Penunjang. M. Syam, et.al (Eds). 
Tjetjep Nurasa : Meningkatkan Pendapatan Petani Melalui Difersivikasi Tanaman ...

Puslitbangtan. Badan Litbang Pertanian. Hal 1811-1812.

Suhardjo, A.J. 1997. Stratifikasi Kemiskinan dan Disribusi Pendapatan di Wilayah Pedesaan (Kasus Tiga Dusun Wilayah Karang Selatan, Gunung Merapi, Jawa Tengah). Majalah Geografi Indonesia No. 19 Th. 11, Maret 1997, Fakultas Geografi Universitas Gadjah Mada, Yogyakarta. Hal. 69-86.

Supriyati, Saptana, dan H.P.S. Rachman. 2005. Perkembangan dan Determinan Diversifikasi Usahatani di Lahan Sawah. (Tidak dipublikasikan).
Supriyati, Saptana dan Yana Supriyatna 2003 soca Hubungan Penguasahaan Lahan dan Pendapatan Rumahtangga di Pedesaan (Kasus Di Propinsi Jawa Tengah, Sumatera Barat Dan Kalimantan Barat)A Pusat Penelitian dan Pengembangan Sosial Ekonomi Pertanian, Bogor

Susilowati, S.H., Supadi, dan C. Saleh. 2002. Diversifikasi Sumber Pendapatan Rumah Tangga di Pedesaan Jawa Barat. Jurnal Agro Ekonomi 20(1): 85 - 109.

Sukartawi,2002. Agribisnis Teori dan Aplikasinya. Rajawali. Press. Universitas Brawijaya. Jakarta. 